\title{
Event tourism as a promising area of social and economic development of the Rostov region
}

\author{
Galina Ekinil ${ }^{1, *}$, Antonina Petrenko ${ }^{1}$, and Olga Dudkina ${ }^{1}$ \\ ${ }^{1}$ Don State Technical University, Gagarina Sq., 1, Rostov-on-Don, 344003, Russia
}

\begin{abstract}
This study aims to identify the role of event tourism in the socio-economic development of the territory. The article presents approaches to event tourism, studies the characteristics of event tourism, describes the stages of formation of event tourism in the Russian Federation, describes a successful experience in the development of event tourism in the Rostov region, and also identifies factors that restrain the development of event tourism.
\end{abstract}

\section{Introduction}

Tourism in the Russian Federation is one of the most promising branches of the modern economy. One of the ways to effectively use the tourist potential of a territory that can attract tourists to the region in a relatively short period of time with a relatively small amount of costs is event tourism.

In world practice, the term "event tourism" is used to denote the term "event tourism".

The tourist flow attracted by event tourism in Russia is about $30 \%$ and has a tendency to increase. The leaders of event tourism in Russia are Moscow and St. Petersburg, where the largest number of cultural events take place. In the Rostov region, the share of event tourism is $40 \%$ in the entire structure of the tourism industry; the development of event tourism makes it possible to attract the attention of federal and regional mass media and improve their image.

At the same time, although the Russian tourism market offers a wide range of event tours, they are significantly inferior to competing countries in terms of their scale and amount of funding. Also, due to the fact that this direction of tourism in Russia is at the stage of formation, the potential has not been realized - many events held in Russian regions are not aimed at tourists, but are of a non-commercial or image nature. Also, due to the lack of a methodological base, in general, the impact of the event market on tourist flows and the regional economy is not assessed.

All this indicates the relevance of the topic and requires further research.

The purpose of the work is to study the impact of event events on the development of regional tourism in the Rostov region.

To achieve this goal, the following tasks were solved in the work: the characteristics of event tourism were studied, the stages of the formation of event tourism in the Russian Federation were given, a successful experience in the development of event tourism in the

\footnotetext{
*Corresponding author: gekinil@mail.ru
} 
Rostov region was described, and the factors that hinder the development of event tourism were identified.

\section{Materials and methods}

Among foreign authors, Y. Mansour, H. Sabry, M. Refat, A. Wagdy, 2020 [1], C. Fenu, F. Pittarello, 2018 [2], B. I. Farahat, K.A. Osman, 2018 [3], X. Luo, P. Song, Y. Wang, W. Tian, Z. Gu, 2016 [4], M. Napp, T. Kalamees, T. Tark, E. Arumägi, 2016 [ 5], J. Pallud, DW Straub, 2014 [6].

The research methodology of tourism in the context of regional specifics is devoted to the works of such authors as: S. Karampela, D. Kavroudakis, T. Kizos, 2019 (experience of Greece) [7], T.Y. Dewanti, D. Susiloningtyas, Supriatna, 2019, (experience of Indonesia) [8], S. Li, C. Li, J. Li, 2019, (experience of China) [9], J. Cheng, JingXu, ZhenfangHuang, 2019 [10], SamiChaabouni, 2019 [11], VirgilNicula, SimonaSpânu, RoxanaElenaNeagu, 2013, (the experience of Romania) [12], DanielaDoinaFundeanu, 2015 [13], HAM Shaffril, A. Hamzah, S. Md. Yassin, B.A. Samah, J.L. D'Silva, N. Tiraieyari, M. Muhammad [14], Thanks to their research, this type of tourism stood out as an independent branch of science with its own terminological apparatus and began to be considered as a separate direction.

On the other hand, the features of innovations in the tourism and hospitality industries were studied, reflected in the works: S. Wang, K.Hung 2015 [15], Ivanov V., Popov S., Dontsov N., Ekinil G., Oleynikova Ju., Denisenko Ju. 2020 [16], Valeria Provotorina, Lyudmila Kazmina, Antonina Petrenko, Galina Ekinil 2020 [17], Galina Ekinil, Lyubov Gorgadze and Oksana Yuryeva [18] A. Mai Walder, 2017 [19], J. Chun-Chung Chow, Cheng Ren, Brenda Mathias, Jiaying Liu 2019 [20], Meiju Keinänen, Jani Ursin, Kari Nissinen 2018 [21], Viv Ellis, Ann Childs 2019 [22], Nicole C. Jackson 2019 [23], Ekinil, G., Gorgadze , L., Provotorina, V., Petrenko, A. [24, 25].

Among the main methodological approaches used in organizing event tourism, one should single out the systemic, institutional and integrated approaches. They provide an opportunity to study the trends and processes taking place in tourism activities. In the course of the study, a typological approach is also used, which makes it possible to characterize not only the current trends and constraints in the development of event tourism, but also to identify possible prospects for this process. The scientific provisions, conclusions and recommendations contained in the article are based on the use of combined methods of historical and logical analysis.

\section{Results}

Currently, there is a comprehensive development of domestic and inbound tourism in the Russian Federation by creating conditions for the formation and promotion of a highquality and competitive tourist product in the domestic and international tourist markets. The program of event tourism is being updated and the national calendar of events is being modernized with its integration into a digital platform for tourism development. Russia hosts massive international federal and regional events aimed at attracting tourists to the regions of Russia.

Every year the Rostov region is visited by about a million tourists. The tourist resource of the region includes up to 800 objects of the tourism industry.

The main flow of tourists $(71.9 \%)$ enters the Rostov region by personal automobile transport, another $20.9 \%$ by buses. The federal highway M-4 "Don" passes through the region. $4.4 \%$ of tourists use railway transport. In the regional center is located one of the 
largest junction railway stations of the Rostov region - Rostov-Glavny, with direct and transit communication with which in summer the cities of Belarus, Ukraine, Abkhazia, all federal districts of Russia, except for the Far East, have a direct and transit connection. $1.5 \%$ arrive in the region by air to the only airport in Rostov-on-Don that receives passenger aircraft. The main waterway of the Rostov region, the Don River, is connected by the Volga-Don canal with the Volga, which makes it possible to provide communication by water transport with the Volga cities, as well as with Moscow. $1.5 \%$ of tourists visiting the Rostov region use cruise ships. In addition to the regional center, cruise tourism centers are the villages of Starocherkasskaya and Romanovskaya, the city of Konstantinovsk.

The main resources of the tourist potential of the Rostov Region include places associated with famous natives of the region: Mikhail Alexandrovich Sholokhov (State Museum-Reserve of M., Anton Pavlovich Chekhov (House-Museum of A.P. Chekhov in Taganrog), Anatoly Kalinin, Alexander Solzhenitsyn, Emperor Alexander I (the palace of Alexander I in Taganrog), military leaders A. Suvorov ("Suvorov's House"), S. Budenny (House-Museum of S. M. Budenny), etc. About eight thousand archaeological objects of cultural heritage have been discovered on the territory of the Rostov Region.

In the region there are prospects for the development of cognitive, water, ecological, rural, ethnographic, "wine" (festival "Donskaya Vine") and other types of tourism. Summer holidays on the coast of the Azov Sea are gaining popularity, the most common beach holidays are in Taganrog, the Neklinovsky district, on the Pavlo-Ochakovskaya spit and near the Chumbur-Kos farm.

In 2020, a museum complex of the Great Patriotic War "Sambek Heights" was opened in the region, similar to the Moscow museum on Poklonnaya Gora, the football stadium "Rostov Arena" was built as part of the program of the 2018 FIFA World Cup in Russia.

There are 9 professional theaters (including two theaters for children and youth), a circus, 49 museums, 14 health resorts with healing natural healing factors (mineral waters, therapeutic mud), 54 stadiums, each of which is designed for more than 1,500 spectators.

Another interesting reason for traveling across the Don land is various event events, historical game reenactments and theatrical performances, which have become increasingly popular lately. In the Rostov region, such events include:

- All-Russian literary and folklore festival "Sholokhov spring" (Vyoshenskaya station and Kruzhilinsky village, Sholokhovsky district),

- Interregional festival of Cossack folklore "There is no more freedom than the quiet Don!" (Starocherkasskaya station, Aksay district),

- Literary and folklore festival "Kalinin Summer" (Pukhlyakovsky village, Ust-Donetsk region),

- Literary and ethnographic holiday "Kruzhilinsky clean-ups" (Kruzhilinsky village, Sholokhovsky district),

- Reconstruction of "The Lay of Igor's Regiment" (Kayal Readings, Kh. Pogorelov),

- Festival "Defense of Taganrog 1855" (Taganrog),

- Reconstruction of the events of 1641 "Siege of Azov",

- Reconstruction of the events of the Great Patriotic War "Breakthrough of the Mius Front".

All these events gather thousands of guests not only from the region, but also from all over the country.

Festivals based on historical reenactments, such as "The Siege of Azov in 1641", are especially popular today; events reflecting the wine and gastronomic traditions of the region, such as the "Festival of the Don fish soup" and the festival "Don vine".

Event activities can be divided, taking into account the classifying signs, into the following types:

- by the nature of events (entertainment and business, open and closed, large-scale and 
local, etc.);

- by frequency (one-time, multiple);

- place of formation (internal, external);

- method of initiation (natural / genuine, artificial / special).

According to the thematic criterion, event tourism can be divided into national festivals and holidays, theatrical shows, film and theater festivals, gastronomic festivals, festivals and flower exhibitions, fashion shows, auctions, music festivals and music competitions, sporting events, technical salons.

Researchers identify various features of event tourism. By summarizing all opinions, a complete picture of the distinctive characteristics of event tourism can be obtained (Figure $1)$.

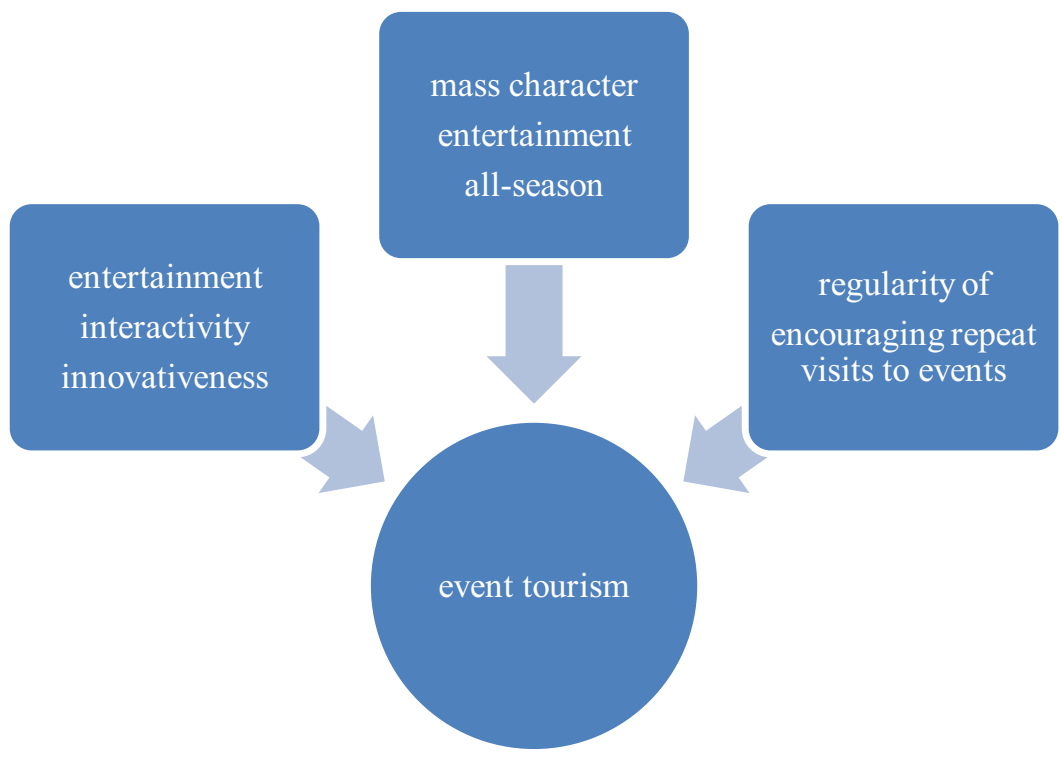

Fig. 1. Characteristics of event tourism.

Due to the above characteristics, event tourism has certain advantages for development in the region in comparison with other types of tourism (Table 1):

- event tourism can attract a large flow of tourists to the region;

- the development of this direction helps to solve the problem of seasonality;

- the time spent by tourists in the region increases (if the event is long);

- event tourism reflects the interests of different target audiences;

- this direction does not require the presence of natural resources on the territory.

Table 1. Comparative characteristics of different types of tourism.

\begin{tabular}{|c|l|c|c|c|c|}
\hline No. & Type of tourism & season & $\begin{array}{c}\text { resource } \\
\text { orientation }\end{array}$ & $\begin{array}{c}\text { Ability to } \\
\text { generate } \\
\text { tourist } \\
\text { traffic }\end{array}$ & $\begin{array}{c}\text { The breadth } \\
\text { of coverage } \\
\text { of the tourist } \\
\text { audience }\end{array}$ \\
\hline 1 & $\begin{array}{l}\text { Cultural } \\
\text { educational }\end{array}$ & + & + & + & + \\
\hline 2 & Environmental & + & + & + & + \\
\hline 3 & Rural & + & - & - & - \\
\hline 4 & Health and wellness & + & - & - & - \\
\hline 5 & Event & - & - & + & + \\
\hline
\end{tabular}




\begin{tabular}{|l|l|c|c|c|c|}
\hline 6 & Hunting-fishing & + & + & - & \\
\hline 7 & Recreational (beach) & + & + & + & + \\
\hline 8 & Business & - & - & - & - \\
\hline
\end{tabular}

In addition, according to experts, event tourism is beneficial for development in a territory that does not even have unique tourist resources. According to the researchers, event tourism is an effective development tool in the context of the economic crisis. Also, successful events have a positive effect on the image of the territory beyond its borders.

In the Rostov region, the share of event tourism is $40 \%$ in the structure of the tourism industry.

Event events in all their diversity and all varieties are an unusually complex cultural phenomenon. At first glance, the organization of event events seems to be a simple process that creates the impression of a purely technical work.

In the process of preparing the organization of a mass event, due attention should be paid to the development of the event scenario itself, the selection of a place where the event will be held. It is also very important to carry out the design concept, if necessary, interact with catering establishments (field service), as well as organize the safety of all participants.

First of all, you need to pay attention to the process of planning the main stages of organizing an event, taking into account some parameters:

- Timeliness, which consists in a correctly chosen place for organizing the event and the time for its holding;

- the grandeur, i.e. the use of action elements that delight the audience and all participants in the event;

- the opportunity to relax, since participants come to such events to relax, to escape from the everyday hustle and bustle;

- involvement. Maximum participation in interactive play areas, joint performance of songs, invitation of participants to the stage will give positive emotions and pleasant memories.

\section{Discussion}

What events motivate foreign tourists to go to Russia is discussed in a joint study of the Visit Russia network of national tourism offices and the federal project EventsInRussia.com.

The study was conducted in May 2017 in China, Europe, the Middle East and Southeast Asia with the support of the National Tourism Offices Visit Russia. The research results demonstrate that an event itself (festival, holiday, concert, natural phenomena, sporting events, historical reenactments, etc.) can become a reason to visit Russia - $73 \%$ of respondents answered that they are interested in the eventual possibilities of Russia.

At the same time, the most important role in the choice of event events in Russia for a tourist to visit is played by the "popularity of the event", that is, the presence of positive associations or knowledge about the event itself, the place of its holding ( $63 \%$ of the respondents answered this way). In second place is the content, the informative program of the event (54\%), followed by the advertisement of the event and the availability of a readymade tour, including the event (37\% each). But the venue and the presence of nearby attractions play a relatively small role. 


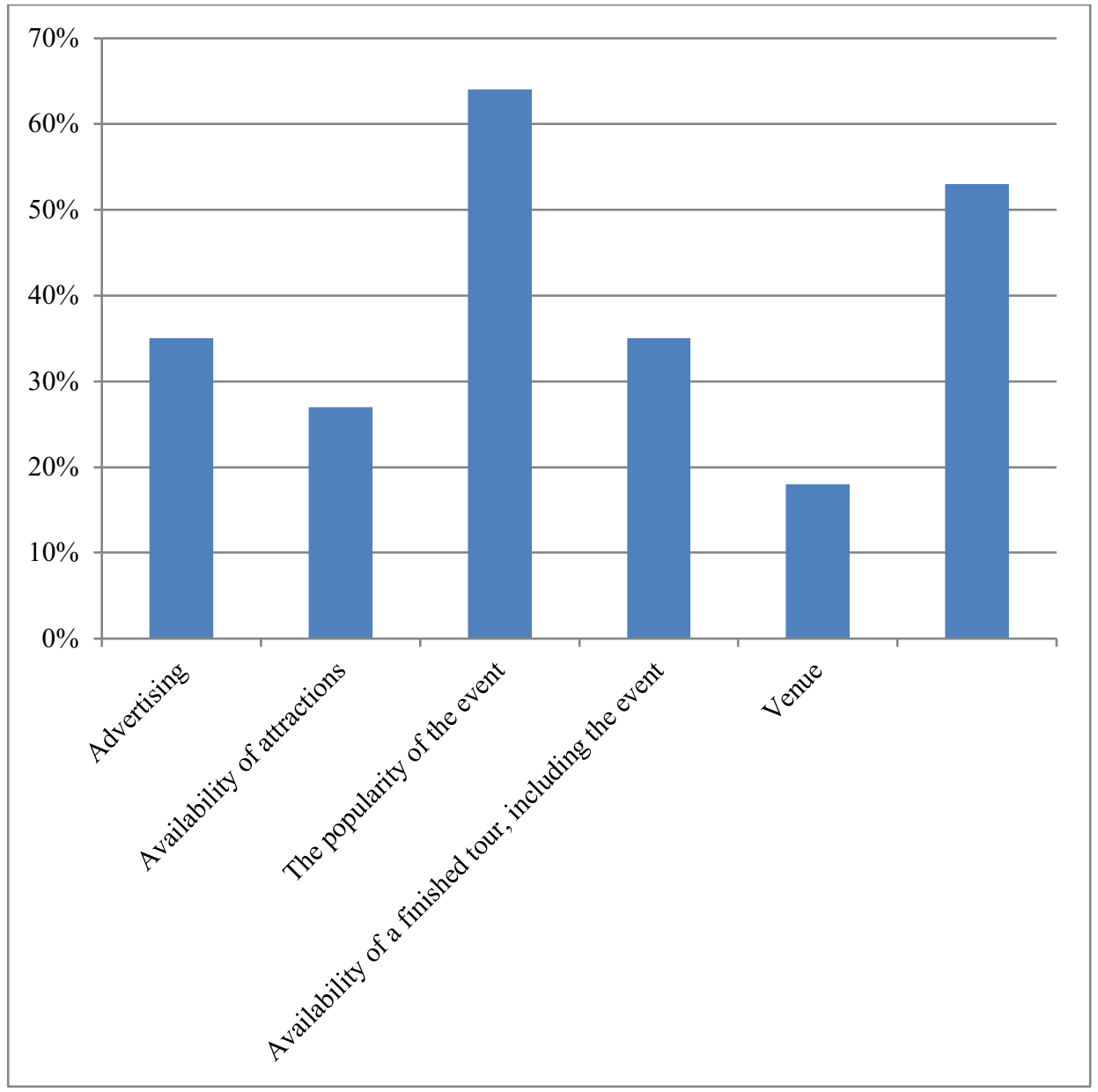

Fig. 2. The main criteria for selecting event events.

The most popular topic that arouses the interest of foreign guests was the one associated with a unique natural phenomenon, such as the flowering of tulips. Historical reconstructions and sports events ranked second, while traditional holidays and gastronomic festivals ranked third. Foreigners are least interested in film and music festivals in Russia.

In general, the degree of interest of foreigners in different types of thematic events is reflected in the bar chart. 


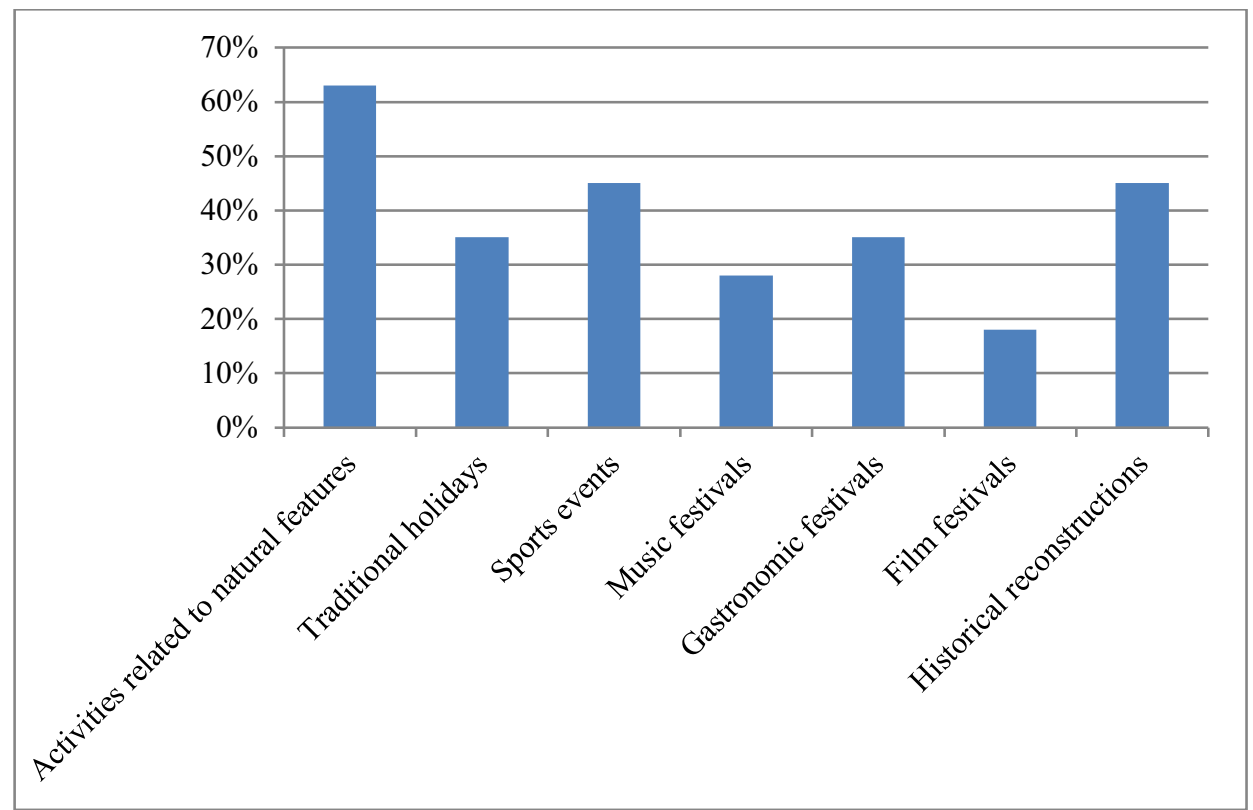

Fig. 3. The degree of interest of foreigners in different types of thematic events.

The study also revealed that an interesting topic alone is not enough for foreign tourists to make a decision to travel to Russia. The most important additional incentive to visit a festival or holiday, judging by the survey results, is "the opportunity to become a direct participant in the festival" (which speaks of the importance of the interactive component). In second place is "gaining new knowledge" (which, in turn, indicates the need for nonstandard content of events).

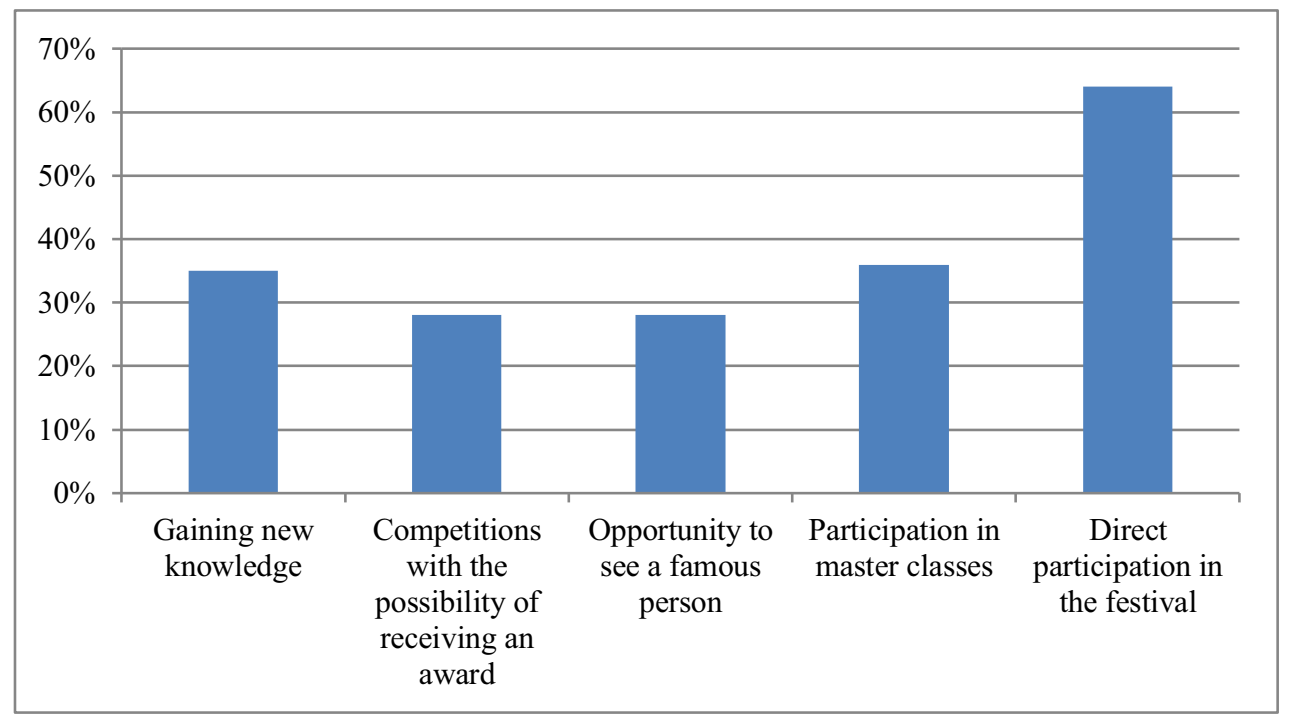

Fig. 4. The main purposes of attending events.

In order to bring a tourist event to the foreign market, in addition to ensuring a high level of organization of the event, systematic professional promotion of the region in which 
the event takes place is necessary in foreign markets. Foreign respondents noted a lack of information as the main constraint to promoting tourism opportunities in Russian regions.

According to the research, travel agencies are the main source of information about tourist events for potential foreign tourists. They are followed by print media. Oddly enough, the internet and social media are in third place. Thus, a direct connection with the tourism market of the country of interest is an important part of the strategy for promoting event tourism products.

The specialists of Visit Russia and EventsInRussia.com believe that in order for individual or organized groups of tourists to come to events, the event must be promoted at least a year before the event. At the same time, any placement (Internet, TV, advertising in magazines or presentation in travel agency materials) implies the provision of the necessary minimum of information: a bright text about the event, accompanied by high-quality visuals (photo / video).

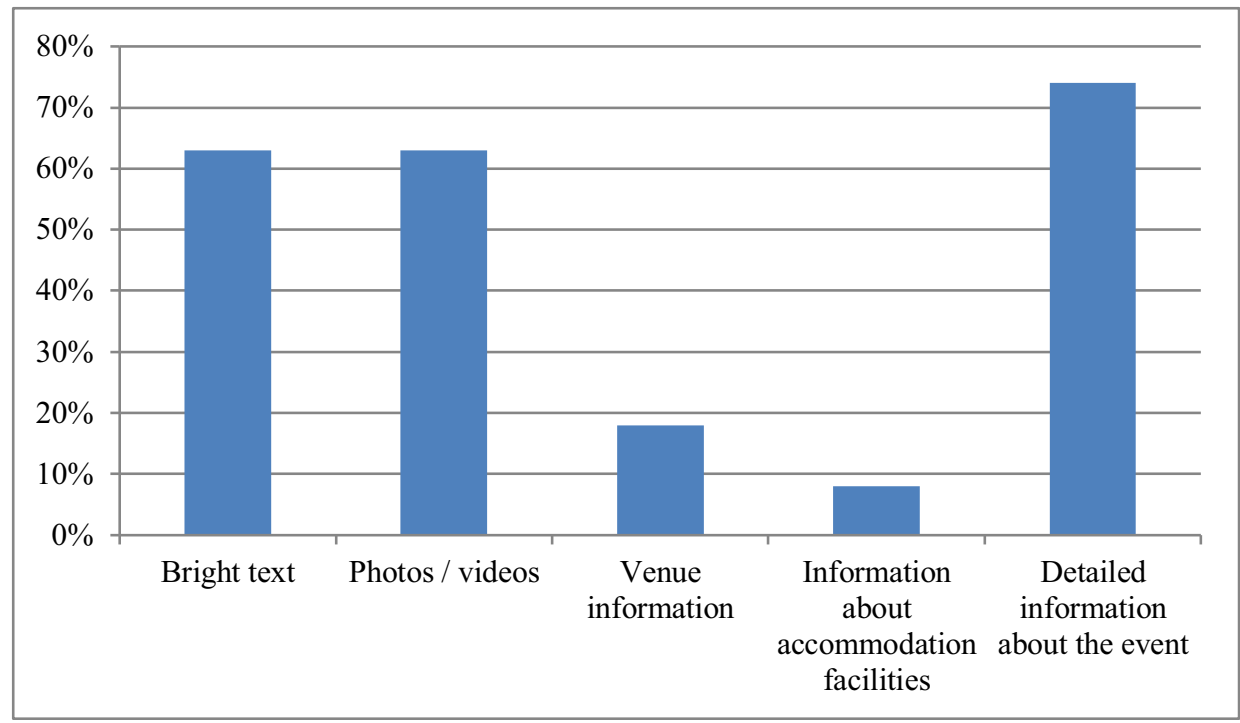

Fig. 5. Information elements.

For effective promotion, it is worth providing information about the event both in electronic form (electronic presentation) and in print (catalogs, booklets, brochures, etc.). Both options were chosen by the majority of the respondents.

Evaluating the effectiveness of the events held is an important component of the marketing policy process, which consists in tracking the impact of the chosen methods of introducing marketing communications on the capital growth process. Usually, the results are presented in the form of an analysis of questionnaires for assessing participants, preparing a statistical analysis of the composition of participants, analyzing an event project in terms of organization and recommendations for subsequent events, analyzing media activity, preparing an analytical report on the event and sending letters of thanks to all its participants.

Table 2. The effectiveness of the organization of events.

\begin{tabular}{|l|l|}
\hline \multicolumn{1}{|c|}{ Purpose } & \multicolumn{1}{|c|}{ Efficiency } \\
\hline $\begin{array}{l}\text { making a profit directly from the event itself } \\
\text { (selling something) }\end{array}$ & $\begin{array}{l}\text { the number of products sold and the ratio of } \\
\text { income from the event and costs for it }\end{array}$ \\
\hline profit growth in the short or medium term & $\begin{array}{l}\text { sales growth, increase in the number of } \\
\text { customers }\end{array}$ \\
\hline
\end{tabular}




\begin{tabular}{|l|l|}
\hline $\begin{array}{l}\text { drawing public attention to a product, service } \\
\text { or problem }\end{array}$ & number of mentions in the media \\
\hline presentation of a new product (service) & sales growth \\
\hline $\begin{array}{l}\text { informing, training and sharing experiences } \\
\text { between the participants of the event }\end{array}$ & $\begin{array}{l}\text { increasing the level of competence and } \\
\text { professional literacy of the participants of the } \\
\text { event }\end{array}$ \\
\hline finding partners and expanding business ties & $\begin{array}{l}\text { the number of new partners ready for business } \\
\text { interaction }\end{array}$ \\
\hline
\end{tabular}

The order of the event event must provide for a clear organization of the movement of the implementation of events, the rules for considering issues, forms for completing the content, determining procedural issues, that is, displaying the structure of the event content verified in time.

\section{Conclusions}

At the same time, it is necessary to highlight a number of factors that negatively affect the development of event tourism:

- poorly developed tourist infrastructure;

- low investment and business activity of the local population;

- lack of qualified personnel;

- weak informational promotion of the event;

- poor use of tourism potential.

An event event has a complex structure, expressed in a quality organization. Despite the complex organization of the process, the organization and conduct of event events is becoming an increasingly popular method that is gaining momentum among enterprises for which it is important to hold an event in order to realize their marketing goals. In shaping the image of an enterprise, this is one of the most effective tools. The best effect as a result of holding and organizing an event is the fact that the consumer, the participant of the event, did not understand that he was exposed to advertising technologies, since they should not be noticeable in a professional approach to planning and carrying out projects.

Thus, event tourism plays an important role in solving the socio-economic problems of territories. At the same time, the inclusion of event tourism in long-term development programs adopted by local authorities is gaining particular relevance. These documents should include subsidizing funds for the development of tourism infrastructure, an action plan for personnel training, a wide range of measures in the field of information promotion of event tours. The implementation of the above measures will positively affect the socioeconomic situation of the territory.

\section{References}

1. F. Fathy, Y. Mansour, H. Sabry, M. Refat, A. Wagdy, Solar Energy 204(1), 673-682 (2020) doi.org/10.1016/j.solener.2020.05.014

2. C. Fenu, F. Pittarello, International Journal of Human-Computer Studies 114, 20-35 (2018) doi.org/10.1016/j.ijhcs.2018.01.009

3. B.I. Farahat, K.A. Osman, HBRC Journal 14(1), 66-78 (2018) doi.org/10.1016/j.hbrcj.2016.01.004

4. X. Luo, P. Song, Y. Wang, W. Tian, Z. Gu, Energy Procedia 104, 431-436 (2016) doi.org/10.1016/j.egypro.2016.12.073 
5. M. Napp, T. Kalamees, T. Tark, E. Arumägi, Energy Procedia 96, 592-600 (2016) doi.org/10.1016/j.egypro.2016.09.105

6. J. Pallud, D.W. Straub, Information \& Management 51(3), 359-373 (2014) doi.org/10.1016/j.im.2014.02.010

7. S. Karampela, D. Kavroudakis, T. Kizos, Current Issues in Tourism 22(12), 1460-1479 (2019) doi:10.1080/13683500.2017.1379475

8. T.Y. Dewanti, D. Susiloningtyas, IOP Conference Series: Earth and Environmental Science 355(1), 0120553rd (2019) doi:10.1088/1755-1315/355/1/012055

9. S. Li, C. Li, J. Li, Asia Pacific Journal of Tourism Research 24(11), 1079-1091 (2019) doi:10.1080/10941665.2019.1665556

10. Cheng Jin, Jing $\mathrm{Xu}$, Zhenfang Huang, Habitat International 87, 1-10 (2019) doi:10.1016/j.habitatint.2019.03.011

11. Chaabouni Sami, Journal of Destination Marketing \& Management 11, 183-191 (2019). doi:10.1016/j.jdmm.2017.09.002

12. V. Nicula, S. Spânu, R.E. Neagu, Procedia Economics and Finance 6, 530-541 (2013) doi:10.1016/S2212-5671(13)00171-8

13. D.D. Fundeanu, Procedia Economics and Finance 23, 744-749 (2015) doi:10.1016/S2212-5671(15)00501-8

14. H.A.M. Shaffril, A. Hamzah, S.Md. Yassin, et al., Asia Pacific journal of tourism research 3(20), 295-313 (2015) doi:10.1080/10941665.2013.877048

15. S. Wang, K. Hung, International Journal of Hospitality Management 48, 92-101 (2015)

16. V. Ivanov, S. Popov, N. Dontsov et al., E3S Web of Conferences. XIII International Scientific and Practical Conference "State and Prospects for the Development of Agribusiness - INTERAGROMASH 2020” 175, 05023 (2020)

17. V. Provotorina, L. Kazmina, A. Petrenko, G. Ekinil, E3S Web of Conferences. XIII International Scientific and Practical Conference "State and Prospects for the Development of Agribusiness - INTERAGROMASH 2020" 175, 10002 (2020)

18. G. Ekinil, L. Gorgadze, O. Yuryeva, E3S Web of Conferences 210, 18050 (2020)

19. A. Mai Walder, Studies in Educational Evaluation 54, 71-82 (2017) https://doi.org/10.1016/j.stueduc.2016.11.001

20. J. Chun-Chung Chow, Ch. Ren, B. Mathias, J. Liu, Children and Youth Services Review 101, 217-224 (2019) https://doi.org/10.1016/j.childyouth.2019.04.008

21. M. Keinänen, J. Ursin, K. Nissinen, Studies in Educational Evaluation 58, 30-36 (2018) https://doi.org/10.1016/j.stueduc.2018.05.007Get rights and content

22. V. Ellis, A. Childs, Teaching and Teacher Education 77, 277-28 (2019) https://doi.org/10.1016/j.tate.2018.10.020

23. N.C. Jackson, Business Horizons 62, 761-772 https://doi.org/10.1016/j.bushor.2019.08.002Get rights and content

24. G. Ekinil, L. Gorgadze, V. Provotorina, A. Petrenko, IOP Conference Series: Materials Science and Engineering 1001(1), $012118 \quad$ (2020) doi:10.1088/1757899X/1001/1/012118

25. G. Ekinil, V. Provotorina, A. Petrenko, L. Gorgadze, E3S Web of Conferences 217, 05006 (2020) doi.org/10.1051/e3sconf/202021705006 